
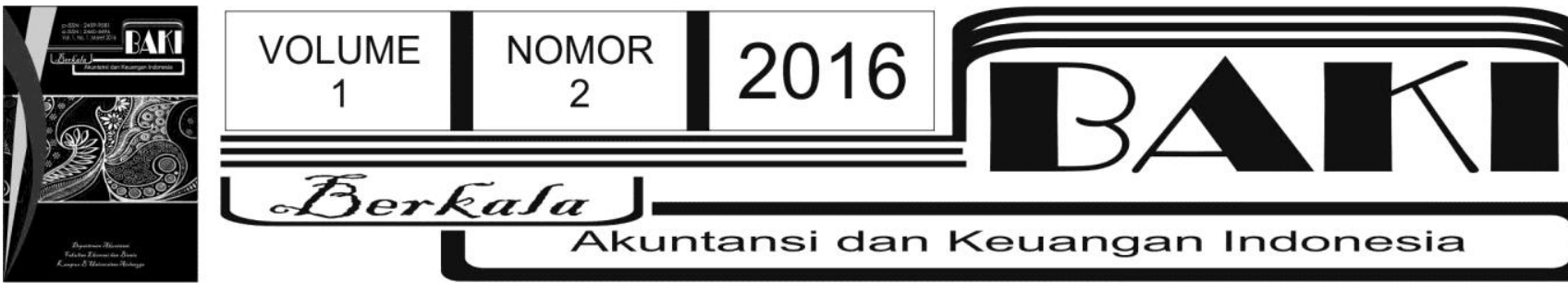

\title{
Berkata
}

Akuntansi dan Keuangan Indonesia

\section{Ketepatan Pasar Modal dalam Memprediksi Kondisi Ekonomi (Studi di Bursa Efek Indonesia)}

\author{
Andry Irwanto*, I Made Narsa \\ *Universitas Airlangga \\ *airwanto@gmail.com
}

\begin{tabular}{|c|c|}
\hline INFO ARTIKEL & ABSTRAK \\
\hline $\begin{array}{l}\text { Histori Artikel: } \\
\text { Tanggal Masuk } 18 \text { Agustus } 2016 \\
\text { Tanggal Diterima } 27 \text { September } \\
2016 \\
\text { Tersedia Online } 30 \text { September } \\
2016 \\
\text { Kata Kunci: } \\
\text { Indeks Harga Saham } \\
\text { Gabungan (IHSG); } \\
\text { Produk Domestik Bruto } \\
\text { (PDB); } \\
\text { inflasi; } \\
\text { S\&P 500; } \\
\text { Nikkei 225 }\end{array}$ & $\begin{array}{l}\text { Penelitian ini menguji ketepatan pasar saham Indonesia dalam } \\
\text { memprediksi kondisi ekonomi Indonesia di masa mendatang. } \\
\text { Kondisi ekonomi diwakili oleh perubahan tingkat Produk Domestik } \\
\text { Bruto dan tingkat Inflasi untuk masa } 3 \text { bulan, } 6 \text { bulan dan } 12 \\
\text { bulan. Perubahan ekonomi dunia diwakili oleh perubahan indeks } \\
\text { saham Amerika Serikat, S\&P 500, dan indeks saham Jepang, } \\
\text { Nikkei } 225 \text {. Waktu penelitian mencakup tahun } 2005 \text { sampai } \\
\text { dengan tahun } 2013 \text {. Sebelum diolah lebih lanjut dilakukan uji } \\
\text { stationer untuk masing-masing variabel dan ditemukan bahwa } \\
\text { seluruh variabel stationer. Hasil menunjukkan bahwa pasar saham } \\
\text { Indonesia tidak mampu digunakan untuk memprediksi kondisi } \\
\text { Ekonomi Indonesia masa mendatang (sampai dengan } 12 \text { bulan) } \\
\text { namun justru lebih dipengaruhi oleh kondisi ekonomi dunia yang } \\
\text { tercermin dari perubahan pasar saham Amerika Serikat. Penelitian } \\
\text { berikutnya dapat diarahkan untuk mencari penyebab ketidak } \\
\text { mampuan pasar saham Indonesia dalam mencerminkan situasi } \\
\text { ekonomi di masa mendatang. }\end{array}$ \\
\hline
\end{tabular}

\section{Pendahuluan}

Secara teori tingkat imbal hasil saham dipengaruhi oleh banyak faktor termasuk didalamnya faktor makro ekonomi. Faktor-faktor ekonomi yang memengaruhinya antara lain adalah pendapatan domestik bruto (GDP), tingkat pengangguran (unemployment rate), inflasi, suku bunga, defisit angggaran (Bodie et al., 2011: 731-732). Selain itu faktor yang menyangkut kondisi internasional juga ikut memengaruhi pergerakan harga saham. Hubungan antara faktorfaktor tersebut dan harga saham menjadi perhatian karena para pelaku ekonomi selalu berusaha mencari indikator-indikator yang dapat mencerminkan perkembangan ekonomi di masa depan. Indikator-indikator tersebut diperlukan dalam rangka mengantisipasi apa yang akan dihadapi nantinya. 
Pada tahun 2008 terjadi krisis keuangan yang dimulai dari Amerika Serikat yang kemudian menjalar ke Eropa dan dampaknya dirasakan oleh hampir semua negara di dunia tak terkecuali Indonesia. Dampak pertama yang dirasakan di Indonesia adalah menurunnya harga-harga saham di Bursa Efek Indonesia saat itu. Pada Nopember 2008 indeks harga saham gabungan (IHSG) sempat menurun pada titik terendah 1.141 setelah pada 2007 pernah mencapai angka 2.810. Penurunan ini diperkirakan karena harapan investor akan turunnya perekonomian dunia akibat krisis keuangan yang melanda Amerika, Eropa, serta negara lain. Penurunan IHSG tidak berlangsung lama karena pada akhir 2009 IHSG telah kembali mencapai angka 2.534 sampai akhirnya pada akhir 2014 menjadi 5.226, sebuah peningkatan yang cukup tinggi, lebih dari $100 \%$. Peningkatan yang terus menerus terjadi pada IHSG tersebut dapat diartikan bahwa investor menganggap ekonomi Indonesia akan sangat cerah di masa depan sesuai dengan teori bahwa pasar modal merupakan leading indicator perekonomian. Namun patut dipertanyakan apakah harapan investor tersebut memang benar-benar mampu digunakan untuk memprediksi perekonomian Indonesia di masa mendatang atau dengan kata lain apakah kenaikan indeks tersebut benar-benar mencerminkan peningkatan perekonomian masa depan. Penelitian tentang harga saham sebagai salah satu indikator yang mendahului perekonomian (leading indicator) telah banyak dilakukan namun penelitian yang mencakup masa krisis keuangan dunia 2008 belum banyak ditemukan.

Penelitian-penelitian yang dilakukan di Amerika Serikat telah mengkonfirmasi bahwa harga saham dipengaruhi oleh faktor-faktor makroekonomi. Ditemukan bahwa imbal hasil saham dengan lag atau lead memiliki hubungan dengan aktifitas ekonomi, dalam hal ini tingkat produksi (Fama 1990; Schwert 1990), dengan inflasi (Geske dan Roll 1983; Park dan Ratti 2000; Kaul 1987).

Selain di Amerika Serikat dan negara maju lainnya, beberapa penelitian mencari hubungan antara makro ekonomi dengan imbal hasil saham di negara-negara berkembang. Dalam lingkup Asia, penelitian telah dilakukan di China, India, serta negara-negara yang tergabung dalam Asean (Hosseini et al., 2011; Lee et al., 2001; Valadkhani et al., 2009; Saji 2013; Alam 2013). Secara umum penelitian-penelitian tersebut menemukan bahwa ada hubungan antara variabel makro ekonomi dan imbal hasil saham. Hubungan tersebut juga merupakan obyek beberapa penelitian yang dilakukan di pasar modal Indonesia.

Penelitian-penelitian yang telah dilakukan di Indonesia memberikan hasil yang berbeda beda. Ada penelitian yang menemukan bahwa tidak ada hubungan antara imbal hasil saham dan faktor ekonomi makro khususnya produk domestik bruto (Kewal 2012 ) sedang penelitian lain menemukan ada hubungan antara faktor ekonomi dan perubahan harga saham (Prasetiono 2010) bahkan dalam masa krisis hubungan ini tetap ditemukan, meskipun inflasi memberikan hasil yang tidak signifikan (Utami dan Rahayu 2003). Selain itu juga ada penelitian yang 
mengkonfirmasi adanya pengaruh ekonomi negara yang lebih maju terhadap ekonomi negara berkembang dalam hal ini Indonesia (Wondabio 2006). Hasil penelitian yang menunjukkan hasil yang berbeda tersebut menimbulkan pertanyaan apakah teori yang berlaku mengenai hubungan faktor makro ekonomi dan harga saham juga dapat diimplementasikan di Indonesia. Harga saham sebagai salah satu leading indicator dari perekonomian seharusnya dapat menangkap sinyal perubahan ekonomi dan merefleksikannya dalam perubahan harga. Pertanyaan lain adalah apakah harga saham di Indonesia hanya dipengaruhi ekonomi negara lain ataukah juga oleh ekonomi fundamental dalam negeri, khususnya bila mencakup masa krisis keuangan dunia 2008.

Penelitian ini mencari hubungan antara perubahan harga saham di Indonesia dengan fundamental ekonomi, dalam hal ini produk bruto domestik dan tingkat inflasi. Dengan berdasarkan konsep saham sebagai leading indicator, akan digunakan lead dari faktor tersebut baik jangka pendek maupun jangka panjang. Yang akan digunakan adalah lead 3 bulan, 6 bulan serta 12 bulan untuk melihat seberapa jauh perubahan harga saham dapat mencerminkan ekonomi dimasa mendatang. Selain itu akan digunakan pula perubahan harga saham negara maju sebagai kontrol mengingat saham negara maju memengaruhi saham negara berkembang.

Penelitian ini menggabungkan pengaruh ekonomi fundamental domestik dan pengaruh ekonomi fundamental negara maju/internasional untuk mengetahui kontribusi dari masingmasing terhadap pergerakan harga saham di Indonesia. Diharapkan hasil penelitian ini dapat mengukur kemampuan harga saham di Indonesia dalam mencerminkan kegiatan ekonomi di masa mendatang sehingga dapat dipakai untuk mengantisipasi perubahan ekonomi domestik. Diharapkan pula hasil penelitian ini dapat memberikan wawasan baru bagi perkembangan teori menyangkut kemampuan harga saham dalam mencerminkan kegiatan ekonomi di masa mendatang, serta hubungannya dengan kegiatan ekonomi negara maju.

Berdasarkan uraian dalam latar belakang maka masalah yang akan diangkat dalam penelitian ini adalah: apakah ada hubungan antara imbal hasil saham di pasar modal Indonesia dengan produk domestik bruto, inflasi, perekonomian negara Amerika Serikat dan perekonomian negara Jepang? Penelitian ini bertujuan menganalisis hubungan antara perubahan harga saham di pasar modal Indonesia dengan produk domestik bruto, inflasi, perekonomian Amerika Serikat, dan perekonomian Jepang.

Hasil penelitian ini diharapkan dapat memberikan wawasan tentang hubungan harga saham dengan faktor fundamental ekonomi domestik serta ekonomi negara maju. Secara praktis hasil penelitian ini memberikan pengetahuan tentang bagaimana harga saham dapat digunakan sebagai ukuran perekonomian masa depan. 


\section{Tinjauan Pustaka}

Secara teoritis harga saham selalu dipengaruhi oleh banyak faktor baik faktor makro ekonomi maupun faktor internal perusahaan itu sendiri (mikro). Faktor makro ekonomi yang dapat memengaruhi harga saham antara lain adalah produk domestik bruto yang mencerminkan kegiatan ekonomi di suatu negara, tingkat inflasi yang dapat mencerminkan perubahan suku bunga yang diharapkan pasar, tingkat pengangguran yang mencerminkan jumlah tenaga kerja yang tidak memperoleh penghasilan rutin. Tingkat pengangguran juga dipengaruhi oleh perubahan tingkat inflasi maupun produk domestik bruto (Bodie et al., 2011: 732; Brown and Reilly 2009: 364).

\subsection{Harga saham dan produk domestik bruto}

Kegiatan ekonomi yang berubah tentu akan mengubah pula harapan arus kas yang diperoleh dimasa mendatang. Laba perusahaan akan berubah seiring perubahan kegiatan ekonomi dan perubahan laba ini akan memengaruhi pula harapan arus kas yang diperoleh perusahaan dimasa mendatang. Perubahan arus kas ini diantisipasi oleh pasar dengan melakukan penyesuaian pada harga saham karena pada dasarnya harga saham merupakan nilai sekarang dari harapan arus kas dimasa mendatang.

Penelitian tentang kegiatan ekonomi dan harga saham memberikan hasil hubungan yang positif baik jangka pendek (satu bulan) maupun jangka panjang (12 bulan) (Fama 1990). Penggunaan data yang lebih panjang, dengan menambahkan tambahan pengamatan 65 tahun menjadi 100 tahun pengamatan, tidak mengubah hasil penelitian tersebut (Schwert 1990). Variasi perubahan harga saham lebih dapat dijelaskan oleh perubahan tingkat kegiatan ekonomi (produksi) jangka panjang dibandingkan kegiatan ekonomi jangka pendek. Dengan menggunakan konsep arbitrage pricing theory, Chen et al. (1986) juga menemukan bahwa pertumbuhan produksi industri berpengaruh terhadap harga saham. Hasil penelitian di Indonesia dengan menggunakan indeks LQ45 juga menemukan bahwa pertumbuhan ekonomi memengaruhi perubahan harga saham. Penelitian ini menggunakan Error Correction Model (ECM) dalam analisisnya (Prasetiono 2010).

\subsection{Harga saham dan inflasi}

Selain itu terdapat faktor makro lain seperti inflasi yang juga dapat berpengaruh terhadap pergerakan harga saham. Inflasi yang diantisipasi akan memiliki efek terhadap suku bunga atau tingkat diskonto. Tingkat diskonto ini akan digunakan oleh pasar untuk menentukan nilai 
sekarang dari saham. Perubahan tingkat inflasi yang diantisipasi segera mengubah pula arus kas dan dengan demikian harga saham akan berubah pula. Secara teori imbal hasil saham akan bergerak searah dengan perubahan harapan inflasi sehingga inflasi merupakan kabar baik bagi pemegang saham.

Temuan penelitian menunjukkan bahwa suku bunga dan perubahan tingkat inflasi merupakan dua hal yang berkaitan dan keduanya menyebabkan imbal hasil saham berubah meskipun dengan arah yang berlawanan. Penjelasan yang diberikan tentang arah yang berlawanan tersebut didasarkan pada teori tentang defisit anggaran yang dibiayai oleh utang sehingga memengaruhi jumlah uang beredar (Geske and Roll 1983). Hubungan yang negatif antara keduanya juga ditemukan dalam penelitian lain (Park and Ratti 2000; Chen et al., 1986).

Penelitian yang dilakukan selama masa krisis di Indonesia tahun 1998 - 2000 menunjukkan bahwa inflasi mempunyai pengaruh negatif terhadap imbal hasil saham namun tidak signifikan (Utami dan Rahayu 2003). Hubungan inflasi yang negatif namun tidak signifikan juga ditemukan oleh Kewal (2009) yang meneliti dalam kurun waktu 2000-2009.

\subsection{Harga saham dan perekonomian dunia}

Dalam era globalisasi perekonomian suatu negara akan semakin terbuka. Keterbukaan ini dapat terlihat dari transaksi internasional berupa ekspor-impor ataupun penanaman modal di negara lain maupun hubungan dalam sektor keuangan. Hubungan antar negara juga semakin intensif sehingga apa yang terjadi di satu negara memiliki dampak terhadap negara lain. Negara maju dengan perekonomian yang lebih kuat cenderung memiliki pengaruh bagi negara berkembang yang perekonomiannya lebih lemah. Perubahan perekonomian di negara maju akan memengaruhi perubahan perekonomian di negara berkembang. Harga saham sebagai salah satu leading indicator dapat mencerminkan kegiatan perekonomian suatu negara di masa mendatang sehingga perubahan harga saham dapat digunakan sebagai ukuran antisipasi terhadap perubahan perekonomian di masa mendatang.

Penelitian di Thailand menemukan bahwa harga saham Singapore berhubungan kuat dengan harga saham Thailand mengingat Singapore adalah pusat keuangan di Asia. Singapore juga melakukan banyak investasi secara regional dan memberikan jasa informasi (Valadkhani et al., 2009). Penelitian di Indonesia yang menghubungkan perkembangan ekonomi negara maju (yang diproksikan dengan indeks harga saham) dan imbal hasil saham menunjukkan bahwa perkembangan di pasar modal London dan Jepang memiliki dampak yang signifikan terhadap pasar modal di Indonesia (Wondabio 2006). 


\section{Metode Penelitian}

\subsection{Jenis Penelitian}

Penelitian merupakan penelitian kuantitatif bersifat eksplanatoris yang mencari hubungan antara variabel imbal hasil saham pasar modal Indonesia dengan pertumbuhan Produk Domestik Bruto (PDB), inflasi, imbal hasil saham di pasar modal Amerika Serikat dan Jepang.

\subsection{Populasi dan Sampel}

Penelitian ini mencakup kurun waktu mulai tahun 2005 sampai dengan tahun 2013. Tahun 2005 dipilih mengingat ketersediaan data dan data tahun 2013 hanya tersedia sampai dengan kwartal-II. Penelitian mengambil Indeks Harga Saham Gabungan dari pasar saham Indonesia yang mewakili seluruh saham yang terdaftar di bursa.

\subsection{Definisi Operasional Variabel}

Variabel yang digunakan dalam penelitian ini adalah sebagai berikut:

1. Imbal hasil saham di Pasar modal Indonesia adalah merupakan imbal hasil yang diperoleh investor apabila berinvestasi di pasar modal Indonesia dalam kurun waktu tertentu. Pasar modal Indonesia diproksikan dengan Indeks Harga Saham Gabungan (IHSG) dan imbal hasil dihitung dengan rumus:

$$
\mathrm{R}_{I H S G(t, t-1)}=\left(I H S G_{t}-I H S G_{t-1}\right) / I H S G_{t-1}
$$

$I H S G_{t}=$ nilai penutupan akhir bulan ke-t

$\mathrm{IHSG}_{\mathrm{t}-1}=$ nilai penutupan akhir bulan ke-(t-1)

2. Pertumbuhan PDB adalah perubahan Produk Domestik Bruto dari satu periode ke periode berikutnya, yang diukur dengan:

$$
\mathrm{DPDB}=\left(\mathrm{PDB}_{\mathrm{t}+1}-\mathrm{PDB}_{\mathrm{t}}\right) / \mathrm{PDB}_{\mathrm{t}}
$$

t menunjukkan bulan dan yang digunakan adalah 3 bulan, 6 bulan dan 12 bulan setelah perhitungan IHSG.

3. Inflasi adalah kenaikan harga secara umum diukur dengan perubahan indeks harga konsumen dari periode sebelumnya, dan data diperoleh dari laporan Badan Pusat Statistik (BPS) untuk periode bulanan. Inflasi yang digunakan adalah inflasi dari bulan-bulan setelah perhitungan IHSG yaitu 3 bulan, 6 bulan dan 12 bulan setelah IHSG.

4. Harga saham di Amerika Serikat adalah imbal hasil indeks saham di New York Stock Exchange yaitu indeks S\&P 500, yang dihitung dengan rumus: 


$$
R_{S P(t, t-1)}=\left(S P_{t}-S P_{t-1}\right) / S P_{t-1}
$$

t menunjukkan bulan dan yang digunakan adalah 3 bulan, 6 bulan dan 12 bulan setelah perhitungan IHSG.

5. Harga saham di Jepang adalah imbal hasil indeks saham di Tokyo Stock Exchange yaitu indeks Nikkei 225, yang dihitung dengan rumus:

$$
\mathrm{R}_{\mathrm{NK}(\mathrm{t}, \mathrm{t}-1)}=\left(\mathrm{NK}_{\mathrm{t}}-\mathrm{NK}_{\mathrm{t}-1}\right) / \mathrm{NK}_{\mathrm{t}-1}
$$

t menunjukkan bulan dan yang digunakan adalah 3 bulan, 6 bulan dan 12 bulan setelah perhitungan IHSG.

\subsection{Jenis dan Sumber Data}

Data yang digunakan pada penelitian ini berupa data sekunder. Data akan diperoleh dari Bursa Efek Indonesia menyangkut IHSG, sedang menyangkut S\&P 500 dan Nikkei 225 akan diperoleh dari Yahoo! Finance. Data mengenai produk domestik bruto (PDB) dan inflasi diperoleh dari website Badan Pusat Statistik (BPS).

\subsection{Model Analisis}

Model analisis yang digunakan dalam penelitian ini adalah model regresi linier berganda:

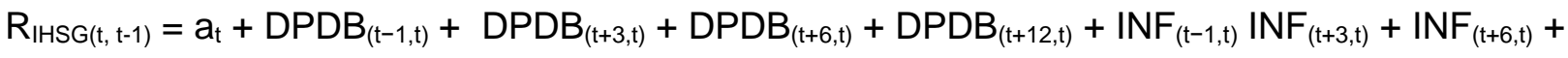

$$
\begin{aligned}
& I N F_{(t+12, t)}+R_{S P(t, t-1)}+R_{N K(t, t-1)}+e_{t}
\end{aligned}
$$

dengan

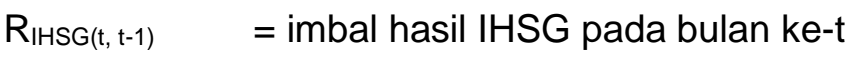

$\mathrm{DPDB}_{(\mathrm{t}+\mathrm{T}, \mathrm{t})}=$ perubahan produk domestik bruto pada bulan ke-t+T dan $\mathrm{T}=1,3,6$ dan 12

$\mathrm{INF}_{(\mathrm{t}+\mathrm{T}, \mathrm{t})} \quad=$ inflasi yang terjadi pada bulan ke t sampai $\mathrm{t}+\mathrm{T}$ dan $\mathrm{T}=1,3,6$, dan 12

$R_{S P(t, t-1)}^{=}=$imbal hasil indeks S\&P 500 pada bulan ke-t

$\mathrm{R}_{\mathrm{NK}(\mathrm{t}, \mathrm{t}-1)} \quad=$ imbal hasil indeks Nikkei 225 pada bulan ke-t

$\mathrm{e}_{\mathrm{t}} \quad=$ kesalahan galat regresi (residual error)

Mengingat data yang dipakai adalah data time series maka akan dilakukan pengecekan stationarity dengan menggunakan Augmented Dicky Fuller Test (ADF).

\subsection{Teknik Analisis}

Untuk menjawab rumusan masalah maka pekerjaan yang akan dilakukan dalam penelitian ini adalah sebagai berikut:

1. Menghitung imbal hasil IHSG bulanan dari Bursa Efek Indonesia 
2. Menghitung perubahan PDB Indonesia 1 bulan, 3 bulan, 6 bulan serta 12 bulan sesuai dengan definisi operasional variabel

3. Mengumpulkan data tingkat inflasi Indonesia baik 1 bulan, 3 bulan, 6 bulan maupun 12 bulan

4. Menghitung imbal hasil indeks S\&P 500 dari New York Stock Exchange secara bulanan

5. Menghitung imbal hasil indeks Nikkei 225 dari Tokyo Stock Exchange secara bulanan

Melakukan regresi sesuai dengan model analisis dan melakukan uji signifikansi masing-masing koefisien serta melakukan analisis.

\section{Analisis dan Pembahasan}

\subsection{Deskripsi Data Penelitian}

Hasil pengumpulan data menghasilkan data yang dimulai bulan Januari 2005 sampai dengan April 2013. Data yang menyangkut sebelum tahun 2005 tidak dapat diperoleh, begitu pula dengan data penelitian setelah April 2013. Deskripsi data yang diperoleh dapat dilihat dalam table berikut:

Tabel 4.1.1.

Deskripsi Variabel Penelitian

\begin{tabular}{|l|l|l|l|l|l|}
\hline & IHSG & Infl t & Infl t+3 & Infl t+6 & Infl t+12 \\
\hline Mean & $-0,003502$ & 0,008737 & 0,018580 & 0,017891 & 0,035574 \\
\hline Median & 0,004105 & 0,006700 & 0,015800 & 0,014100 & 0,025600 \\
\hline Maximum & 0,112644 & 0,087000 & 0,099700 & 0,099700 & 0,119900 \\
\hline Minimum & $-0,111824$ & $-0,003100$ & $-0,001600$ & $-0,001600$ & 0,002000 \\
\hline Std. Dev. & 0,053718 & 0.015362 & 0,017882 & 0,017826 & 0,026613 \\
\hline Skewness & $-0,05285$ & 3,99104 & 2,79510 & 2,92036 & 1,91101 \\
\hline Kurtosis & 2,52375 & 2,06377 & 1,32032 & 1,38144 & 6,53887 \\
\hline
\end{tabular}

Tabel 4.1.2.

Deskripsi Variabel Penelitian

\begin{tabular}{|l|l|l|l|l|l|l|}
\hline & PDB t & PDB t+3 & PDB t+6 & PDB t+12 & Nikkei & S\&P \\
\hline Mean & 0,03988 & 0,03824 & 0,03682 & 0,03659 & $-0,003730$ & $-0,003960$ \\
\hline Median & 0,04100 & 0,03900 & 0,03800 & 0,03800 & $-0,006228$ & 0,010674 \\
\hline Maximum & 0,10000 & 0,10000 & 0,10000 & 0,10000 & 0,104599 & 0,057364 \\
\hline Minimum & $-0,02800$ & $-0,02800$ & $-0,02800$ & $-0,02800$ & $-0,116546$ & $-0,109931$ \\
\hline Std. Dev. & 0,02927 & 0,02968 & 0,02961 & 0,02939 & 0,056824 & 0,040414 \\
\hline Skewness & $-0,34825$ & $-0,22890$ & $-0,11813$ & $-0,11334$ & $-0,11686$ & $-0,78081$ \\
\hline Kurtosis & 2,72023 & 2,56377 & 2,54848 & 2,60154 & 2,28509 & 2,91670 \\
\hline
\end{tabular}

Dari tabel 4.1.1. dan tabel 4.1.2. dapat diketahui bahwa seluruh variabel memiliki kecondongan ke kiri, kecuali variabel inflasi yang memiliki kecondongan ke kanan. Dapat dipahami bahwa inflasi yang digunakan merupakan angka yang selalu positif sedang pada 
variabel lainnya dapat terjadi angka negatif. Kecenderungan variabel selain inflasi lebih banyak yang negatif menunjukkan bahwa dalam periode pengamatan mengalami angka negatif lebih sering daripada positif. Demikian pula dengan kurtosis yang mencerminkan bahwa data tersebut diatas lebih tebal dibandingkan dengan data yang normal.

\subsection{Pengolahan Data}

Berikut ini akan dilakukan pengujian stationeritas variable dan setelah hasil ditemukan akan dilanjutkan dengan analisis regresi antara IHSG dengan variable $\mathrm{PDB}_{t}, \mathrm{PDB}_{t+3}, \mathrm{PDB}_{\mathrm{t+6}}, \mathrm{PDB}_{\mathrm{t}+12}$, $I N F_{t}, I N F_{t+3}, I N F_{t+6}, I N F_{t+12}$, S\&P, dan Nikkei.

\subsubsection{Pengujian Stationeritas Variabel}

Data dalam penelitian ini diolah dengan menggunakan program E-Views. Sebelum melanjutkan ke tahap berikutnya, peneliti melakukan uji terhadap data yang telah dikumpulkan apakah data time series tersebut stationary atau tidak. Pengujian ini diperlukan untuk menjamin bahwa data tersebut dapat digunakan untuk melakukan prediksi. Bila datanya stationary maka data tersebut dapat digunakan lebih lanjut.

Hasil pengujian dengan menggunakan Augmented Dickey Fuller menunjukkan bahwa semua variable yang digunakan yaitu IHSG, PDB $, \mathrm{PDB}_{\mathrm{t}+3}, \mathrm{PDB}_{\mathrm{t+6}}, \mathrm{PDB}_{\mathrm{t}+12}, \mathrm{INF}_{\mathrm{t}}, \mathrm{INF}_{\mathrm{t+3}}, \mathrm{INF}_{\mathrm{t}+6}$, $\mathrm{INF}_{\mathrm{t}+12}$, S\&P, dan Nikkei, adalah stationary pada derajat integrasi 0 dan dengan demikian dapat digunakan dalam model regresi berikutnya. Nilai ADF tersebut seluruhnya signifikan pada level $1 \%$ (tabel 4.2).

Tabel 4.2.

Nilai statistik ADF dan derajat integrasi

\begin{tabular}{|l|c|c|}
\hline \multicolumn{1}{|c|}{ Variabel } & Nilai ADF & $\begin{array}{c}\text { Derajat } \\
\text { Integrasi }\end{array}$ \\
\hline $\mathrm{IHSG}_{\mathrm{HSG}}$ & $-6,481803$ & 0 \\
\hline $\mathrm{PDB}_{\mathrm{t}}$ & $-5,747351$ & 0 \\
\hline $\mathrm{PDB}_{\mathrm{t}+3}$ & $-5,681142$ & 0 \\
\hline $\mathrm{PDB}_{\mathrm{t}+6}$ & $-5,942764$ & 0 \\
\hline $\mathrm{PDB}_{\mathrm{t}+12}$ & $-5,848508$ & 0 \\
\hline $\mathrm{INF}_{\mathrm{t}}$ & $-5,339893$ & 0 \\
\hline $\mathrm{INF}_{\mathrm{t}+3}$ & $-4,94817$ & 0 \\
\hline $\mathrm{INF}_{\mathrm{t}+6}$ & $-5,088624$ & 0 \\
\hline $\mathrm{INF}_{\mathrm{t}+12}$ & $-4,057964$ & 0 \\
\hline $\mathrm{S} \& \mathrm{P}$ & $-5,264106$ & 0 \\
\hline Nikkei & $-5,900317$ & 0 \\
\hline
\end{tabular}




\subsubsection{Analisis Regresi}

Karena seluruh variabel penelitian ternyata stationer pada derajat 0 maka variabel-variabel tersebut dapat langsung digunakan dalam persamaan regresi. Berikut adalah hasil regresi dari variabel-variabel penelitian

Tabel 4.3

\section{Analisis Regresi}

Variabel terikat: IHSG

\begin{tabular}{|c|c|c|c|c|}
\hline Variabel & Regresi -1 & Regresi -2 & Regresi -3 & Regresi -4 \\
\hline Konstan & $-0,0487(0,06)$ & $-0,0141(0,53)$ & $-0,0512(0,10)^{*}$ & $-0,0435(0,07)^{\star}$ \\
\hline $\mathrm{PDB}_{\mathrm{t}}$ & $0,1653 \quad(0,69)$ & & $0,5023(0,44)$ & $0,5435(0,29)$ \\
\hline $\mathrm{PDB}_{\mathrm{t}+3}$ & $0,3896 \quad(0,21)$ & & $0,4791 \quad(0,23)$ & $0,6332(0,05)^{\star *}$ \\
\hline $\mathrm{PDB}_{\mathrm{t}+6}$ & $0,0903 \quad(0,78)$ & & $0,1656(0,67)$ & $0,2256(0,45)$ \\
\hline $\mathrm{PDB}_{\mathrm{t}+12}$ & $0,5913 \quad(0,16)$ & & $0,4285(0,55)$ & $0,4325(0,31)$ \\
\hline $\mathrm{INF}_{\mathrm{t}}$ & & $-1,7089(0,66)$ & $-1,0053(0,55)$ & $-1,8536(0,17)$ \\
\hline $\mathrm{INF}_{\mathrm{t}+3}$ & & $0,7642(0,59)$ & $0,9933(0,49)$ & $1,3342(0,24)$ \\
\hline $\mathrm{INF}_{\mathrm{t}+6}$ & & $-0,4041 \quad(0,47)$ & $-0,6743(0,36)$ & $-0,8218(0,15)$ \\
\hline $\mathrm{INF}_{\mathrm{t}+12}$ & & $0,2784(0,45)$ & $-0,2419(0,61)$ & $-0,5398(0,16)$ \\
\hline S\&P & & & & $0,5576(0,03)^{\star *}$ \\
\hline Nikkei & & & & $0,2442(0,17)$ \\
\hline Adj $R^{2}$ & 0,071 & $-0,088$ & $-0,010$ & 0,399 \\
\hline F Statistic & $(0,19)$ & $0,313 \quad(0,87)$ & $0,956 \quad(0,49)$ & $3,258 \quad(0,01)$ \\
\hline
\end{tabular}

Catatan : Angka di dalam kurung menunjukkan $p$ - value.

Tanda $\left(^{*}\right)$ menunjukkan signifikan pada $10 \%$, tanda $\left(^{* *}\right)$ menunjukkan signifikan pada $5 \%$.

Regresi -1 menguji apakah inflasi memiliki kemampuan menjelaskan perubahan variabel IHSG dan hasilnya menunjukkan bahwa tidak ada satupun variabel inflasi yang signifikan. Demikian pula dengan hasil regresi-2 yang mengkaitkan variabel GDP dengan IHSG tidak menunjukkan hasil yang signifikan.

Dari hasil regresi -3 yang memasukkan semua variabel inflasi dan semua variabel GDP secara bersamaan terlihat bahwa variabel-variabel inflasi dan GDP tersebut tidak memiliki hubungan yang signifikan dengan variabel terikat IHSG. Hal itu terjadi pada variabel dengan lead maupun yang bersamaan dengan variabel terikat IHSG. Pada persamaan regresi -2 saat semua variabel inflasi saja dihubungkan dengan IHSG juga tidak tampak adanya hubungan yang signifikan. Demikian pula dengan regresi -1 yang memasukkan semua variabel GDP, saat dihubungkan dengan IHSG juga tidak ada yang signifikan. Hasil regresi $-1,-2$ dan -3 menunjukkan $R$-square yang tidak signifikan.

Pada persamaan regresi-4 saat dimasukkan variabel S\&P dan Nikkei kedalam persamaan bersamaan dengan seluruh variabel inflasi dan GDP, terlihat bahwa variabel S\&P signifikan pada $5 \%$, sedang variabel-variabel lain tetap menunjukkan hubungan yang tidak signifikan termasuk Nikkei. Persamaan regresi-4 menunjukkan adjusted $R$-square yang cukup tinggi $(0,39)$ serta $\mathrm{F}$ statistik yang signifikan pada level $1 \%$. 


\subsection{Pembahasan}

Teori menyatakan bahwa inflasi seharusnya dipertimbangkan oleh para investor di pasar modal. Inflasi yang diekpektasi akan memengaruhi kemampuan atau daya beli masyarakat sehingga juga akan memengaruhi kemampuan perusahaan dalam menghasilkan laba. Perubahan inflasi yang tinggi akan menyebabkan daya beli turun lebih banyak dan berakibat pada laba yang menurun dan dividen di masa mendatang juga menurun. Hal ini seharusnya berakibat pada perubahan pada harga-harga saham secara keseluruhan di pasar modal. Hasil studi ini menunjukkan bahwa inflasi tidak direspon oleh pasar dan dengan demikian indeks (IHSG) tidak mencerminkan perubahan inflasi di masa mendatang. Hal bertentangan dengan apa yang ditemukan oleh Geske and Roll (1983), Park and Ratti (2000), Chen et al. (1986) namun sejalan dengan temuan dari penelitian Utami dan Rahayu (2003). Hubungan inflasi yang negatif namun tidak signifikan juga ditemukan oleh Kewal (2009). Kemungkinan inflasi tidak menjadi perhatian utama akibat dampak yang dihasilkan inflasi tidak terlalu besar mengingat secara historis inflasi di Indonesia memang selalu tinggi dengan perubahan yang tidak terlalu banyak.

Pertumbuhan ekonomi seharusnya juga harus tercermin dalam harga saham di pasar modal (IHSG) mengingat bahwa pertumbuhan ekonomi akan memberikan efek bagi kemampuan perusahaan untuk menghasilkan laba dan dividen. Pertumbuhan ekonomi Indonesia yang secara historis juga selalu diatas 5\% seharusnya juga dinikmati hasilnya oleh perusahaan publik. Hasil studi ini menunjukkan bahwa harga saham tidak dapat mencerminkan pertumbuhan ekonomi di masa mendatang yang berarti pertumbuhan ekonomi bukan merupakan faktor yang diperhitungkan dalam penetapan harga saham Indonesia. Hal ini tidak sejalan dengan temuan penelitian Fama (1990), Schwert (1990), Chen et al. (1986) serta penelitian yang dilakukan di Indonesia (Prasetiono 2010). Kemungkinan perbedaan pola investasi di Negara maju dan Negara berkembang dapat berbeda dalam hal analisis faktorfaktor yang memengaruhi harga saham. Perbedaan periode penelitian dan metoda dengan yang dilakukan Prasetiono (2010) dapat juga menjadi penyebab perbedaan hasil.

Satu-satunya faktor yang tercermin dalam harga saham (IHSG) adalah situasi perekonomian dunia yang diwakili oleh indeks S\&P 500. Terlihat bahwa faktor ekonomi dunia sangat kuat dipertimbangkan oleh para investor di Indonesia dalam penentuan harga saham. Kemungkinan hal ini juga disebabkan oleh kenyataan bahwa investor asing cukup dominan berinvestasi di Indonesia (kurang lebih 50\%) sehingga investor tersebut sangat mempertimbangkan situasi dunia. Hal ini sejalan dengan Wondabio (2006) meskipun penelitiannya menggunakan indeks dunia yang berbeda. 


\section{Kesimpulan, Keterbatasan, dan Saran}

\subsection{Kesimpulan}

Dari hasil uraian dari bab sebelumnya maka dapat disimpulkan hal-hal sebagai berikut:

1. Inflasi dan pertumbuhan domestik bruto, baik pada saat bersamaan maupun di masa mendatang (dalam hal ini sampai setahun mendatang) ternyata tidak mampu tercermin dalam perubahan harga saham di pasar modal Indonesia. Kemungkinan pasar di Negara berkembang seperti Indonesia kurang memperhatikan faktor dalam negeri dalam berinvestasi.

2. Faktor ekonomi dunia (global) ternyata lebih diperhatikan oleh para investor Indonesia terlihat dari tercerminnya perubahan indeks pasar yang diwakili oleh S\&P 500 dalam perubahan harga saham Indonesia. Salah satu faktor yang mungkin menyebabkan hal ini adalah kenyataan bahwa investor asing masih dominan di pasar Indonesia.

\subsection{Keterbatasan Penelitian}

Penelitian ini menggunakan data Indonesia sejak 2005 sampai dengan 2013 dengan interval triwulanan. Data triwulanan diambil karena tidak tersedianya data bulanan. Apabila menggunakan data bulanan yang akan lebih merata maka hasilnya kemungkinan besar akan berbeda dengan hasil studi ini.

\subsection{Saran}

1. Kemungkinan bahwa pasar modal Indonesia lebih memerhatikan situasi pasar global dibanding situasi ekonomi dalam negeri dapat menjadi pendorong bagi penelitian berikutnya untuk mencari penyebabnya.

2. Penelitian berikut dengan menggunakan data bulanan kemungkinan dapat mengubah hasil studi. Saat ini data yang tersedia dan diperoleh dalam studi ini terbatas hanya pada data triwulanan.

\section{Daftar Pustaka}

Alam, Nafis. 2013. Macroeconomic Variables, Firm Characteristics and Stock Returns during Good and Bad Times: Evidence from SEA, Asian Journal of Finance \& Accounting Vol. 5 no. 2, pp159-182.

Bodie, Zvi., Alex Kane, dan Alan J. Marcus. 2011. Investments and Portfolio Management, Mc Graw Hill/Irwin, $9^{\text {th }}$ Edition, New York. 
Brown, Keith C., dan Frank K. Reilly. 2009. Analysis of Investments and Management of Portfolios, South Western Cengange Learning, $9^{\text {th }}$ Edition, Canada.

Chen, Nai-Fu., Richard Roll, dan Stephen A. Ross. 1986. Economic Forces and the Stock Market, Journal of Business, Vol. 59 No. 3 July, pp 383-403.

Fama, Eugene F. 1990. Stock Returns, Expected Returns, and Real Activity, The Journal of Finance, Vol XLV No. 4 September, pp 1089-1108.

Geske, Robert., dan Richard Roll. 1983. The Fiscal and Monetary Linkage Between Stock Returns and Inflation, The Journal of Finance, Vol 38 issue 1 March, pp 1-33.

Hosseini, Seyed Mehdi., Zamri Ahmad, dan Yeh Wah Lai. 2011. The Role of Macroeconomic Variables on Stock Market Index in China and India, International Journal of Economics and Finance Vol. 3 No. 6 November, pp 233-243.

Kaul, Gautam. 1987. Stock Returns and Inflation, Journal of Financial Economics 18, pp 253276.

Kewal, Suramaya Suci. 2012. Pengaruh Inflasi, Suku Bunga, Kurs, dan Pertumbuhan PDB Terhadap Indeks Harga Saham Gabungan, Jurnal Ekonomia, Vol. 8 no 1, April, pp 5364.

Lee, Chong Lee., Tai Hui Bun, dan Ahmad Zubaidi Baharunshah. 2001. The Stock Market, Macroeconomic Fundamentals, and Economic Growth in Malaysia, Asia Pacific Journal of Economics \& Business Vol. 5 No. 2 December, pp 44-55.

Park, Kwangwoo., dan Ronald A. Ratti. 2000. Real Activity, Inflation, Stock Returns, and Monetary Policy, The Financial Review 35, pp 59-78.

Prasetiono, Dwi Wahyu. 2010. Analisis Pengaruh Faktor Fundamental Ekonomi Makro dan Harga Minyak Terhadap Saham LQ45 Dalam Jangka Pendek dan Jangka Panjang, Journal of Indonesian Applied Economics, Vol. 4 No. 1 Mei, pp 11-25.

Schwert, G. William. 1990. Stock Returns and Real Activity: A Century of Evidence, The Journal of Finance, Vol XLV No. 4 September, pp1237-1257.

Saji, Dr. T.G. 2013. Time Varying Macroeconomic Risk and Industry Stock Returns: Empirical Evidence from India, Asian Journal of Finance \& Accounting Vol 5 No. 2, pp 289-304.

Utami, Muji., dan Mudjilah Rahayu. 2003. Peranan Profitabilitas, Suku Bunga, Inflasi Dan Nilai Tukar Dalam Mempengaruhi Pasar Modal Indonesia Selama Krisis Ekonomi, Jurnal Manajemen dan Kewirausahaan Vol. 5 No. 2, September, pp 123-131.

Valadkhani, Dr. Abbas., Surachai Chancharat, dan Charles Havie. 2009. Analysing the Impact of International Stock Markets and Macroeconomic Variables on the Thai Stock Market, The Business Review, Cambridge Vol. 12 summer, pp 50-56.

Wondabio, Ludovicus Sensi. 2006. Analisa Hubungan Index Harga Saham Gabungan (IHSG) Jakarta (JSX), London (FTSE), Tokyo (NIKKEI) dan Singapura (SSI), Simposium Nasional Akuntansi 9 Padang 23-26 Agustus. 